\title{
Police Strategies in Tackling Fake News and Hoax in Indonesia
}

\author{
Suparno $^{1}$, Sukinta $^{2}$ \\ $\left\{\right.$ kiparno@yahoo.com $\left.{ }^{1}\right\}$ \\ Universitas Diponegoro, Indonesia ${ }^{1,2}$
}

\begin{abstract}
This paper's main problems are the significant spectrums of hoaxes in Indonesia by examining its definition, actors, and discourse as well as analyzing the role of the Indonesian police in tackling hoaxes and the critical challenges faced by them from the policy context. The socio-legal approach is used in this study to provide a contemporary legal perspective in explaining the contemporary issue, such as social media, the internet, the internet of things, cyberspace, and other social issues related to it, such as social media hoax, social media bullying, hate speech, hack, and cybersecurity breach. This paper has ultimately scrutinized and discussed the discourse of hoax and fake news as part of multifaceted information disorder in Indonesia and the National Police of Indonesia or POLRI's policy focus on tackling these information disorders, including hoaxes and fake news.
\end{abstract}

Keywords: Police, Hoax, Indonesia, ITE Law

\section{Introduction}

The hoax case in Indonesia has been increased in the past few years as social media users are also rising at higher numbers. The correlation is proper to be scrutinized further; however, it must be highlighted that according to public polling last year, most of the hoaxes are spread throughout social media users, and $86 \%$ of the internet users have been the victim of hoax [1]. The most concerning issue is when the hoax endangers society and their thoughts. Not only it likely becomes a tool of propaganda, but it becomes a threat for people to access trustworthy information online freely.

Many countries have adopted measures to tackle hoaxes, some remain stagnant, and some indicate hurdles in coping with hoaxes. The case of Indonesia is interesting enough to scrutinize because hoax has been regulated with a national law that becomes the umbrella of internet and electronic transaction (ITE) issues. The regulation in Indonesia to combat hoax is covered under the umbrella of ITE Law No. 19 of 2016. The term 'hoax' is explicitly mentioned in the subarticle 45A, a newly created sub-article to the whole article 45 . Interestingly, article 45 covers not only related to the hoax and its distribution via the electronic medium but also covers the prohibition of the electronic medium used to distribute any information or document that is or include anything against common decency, gambling, defamation, blackmailing, and threats. The sphere of the regulation is perplexing enough to analyze further.

Considering the existing criminal law to handle hoax in Indonesia and the issue has continued to cause concerns, such enforcement is also established to promote action and preemptive approaches in dealing with hoaxes. The fact is under the same ITE law; such 
preemptive measure is correlated to government or institution under government only. The government institution is represented by the Ministry of Communication and Informatics (Kominfo) and the Indonesian National Police (POLRI) as well as the Attorney General of Indonesia as law enforcers. Once the hoax case is affirmative for instance, then the role of the POLRI is legitimate to prosecute the case and report it to District Attorney. Such a policy to support the legal regulation on combatting hoax is crucial and salient. It must be highlighted that hoax causes loss and carries the possibility to create a larger chain of losses. The main question of this journal is to explain how the law enforcer, in this case, Indonesian National Police apply an appropriate policy to combat hoax as well as the field efforts to eschew hoax in Indonesia. Finally, this journal will also scrutinize whether such a policy approach and efforts to combat and minimize hoax have faced any hurdles at all.

The main problems discussed in this paper are: (1) What are the significant spectrums of hoaxes in Indonesia (definition, actors, and discourse)? (2) From the policy context, how does the police of Indonesia tackle hoaxes? (3) What are the police's efforts to eradicate or decrease hoaxes' negative impacts? (4) Besides the efforts, what do police face the key challenges in applying the policy approach?

\section{Research Methods}

To answer these questions, the authors rely on the primary research method and approach by utilizing a socio-legal approach to understand the law implementation. In this research, the approach is applicable because hoax as an issue in society can be observed in both empirical contexts and review via social theories to achieve the findings based on a legal problem-solving approach. The type of data used in this research is secondary data based on legislation, works of literature, as well as statistical findings. This study's overall essence and logic are in the form of legal opinion and field findings. The legal opinion as a problem solver has been recently explained immaculately by Poesoko and Dewi [2] in "justifying whether the legal opinion is a valid method to review social issues from legal perspectives".

Meanwhile, Gijssels and Hoecke [3] explained that "the legal practice position is after the legal dogma, law theory, and law philosophy on the top." In summary, the law creation and application are interconnected to each other. Hence activities that include observing, scrutinize, and expressing critical thinking toward the end to end the journey of lawmaking and application, whether there have been some mishaps or lacking to the regulation as the problem solver of the social issues, can be considered as a method.

\section{Results and Discussion}

\subsection{Beyond Definition: Hoax, Fake News, and Their Complex Dimension}

Hoax is one of the most omnipresent and even flourished issues on the internet today. The hoax is multifaceted and cannot be determined as only fake news but is viewed as a threat. According to UNESCO, what is generally perceived as fake news and hoaxes on social media can be categorized and included within the context of information disorder [4]. Information disorder is a disproportionate form of information due to its subject and objective. The information can be fabricated, misleading, distributed partly, or mean to attack particular actors 
with many forms of published information on social media. However, there are two objectives or goals of the information disorder: falsifying or intending harm. What is being perceived widely as a hoax and fake news in social media can have either one of these objectives or, instead, fall in between the intention (Figure 1).

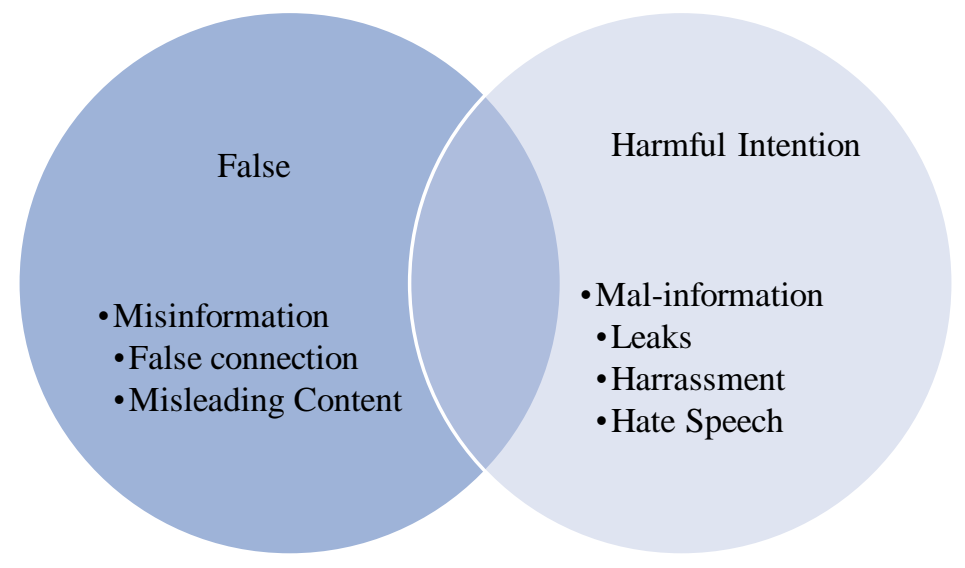

Fig. 1. Information Disorder [4].

What becomes interesting in Indonesia's case is how hoaxes and fake news are often perceived very similarly, even within the legal framework, including the actors' criminalization process behind the false information's creation and distribution process. For instance, both POLRI and Kominfo, as the national government actors to tackle hoax, have not differentiated between a hoax and fake news. Many articles have classified them into different typologies. The media can adopt some hoaxes if the fact-checking process is not considered. However, some fake news is recognized for its originality that is instead genuine and not even in the news [5].

Adhering to ITE law's defects is crucial in defining what is considered fake news and often leads to the actors' disorientation, including governments, national police, court, and even the public comply and uphold the ITE law. Regardless of the urgent need to review and reassess the existing laws, what is more significant is to define what is covered under the ITE Law as the regulation itself has been implemented for years and punishments have taken place at the national level. Failure to define what is considered fake news or hoax, for instance, may lead to difficulty in fighting fake news and hoax. In this paper, the analysis focuses on fake news and hoax as the common negative information disorder found on social media in Indonesia.

\subsection{Chain of Actors Related to Hoax and Fake News}

As earlier mentioned, hoaxes and fake news have not emerged without any intention. Even when its origin is accidental, for instance, the actors who take the role in distributing both hoax and fake news are also part of the vital phase of the hoax or fake news. For instance, in the hoax case, a homemaker living in the suburban area with no intention to cause harm but create viral content by adding comments on top of existing content can lead her content to become a hoax. Nevertheless, under the same hoax umbrella, an actor behind the false information intends on the first hands to create false information ripples of some topics in social media because she or he represents the particular ideology, group, organization, etc. Alternatively, even in the extreme 
hoax scenario, an actor might monetize his or her social media account to create viral information with the aim of falsification, or what we usually know as buzzer who spread the hoax.

Indeed, there are a hundred scenarios of how content can be false and misleading. Unfortunately, it would have been circulated in the future anyhow. Because once posted on the internet, the content trace will stay on the internet. Even if the hoax has been confirmed and the actor has been punished for the crime, the content will remain on the net, and other people might redistribute it, creating another loop of hoax circle. Therefore, it is crucial to understand the whole circle of a hoax because there are important actors responsible for creating, circulating, or even recirculating.

Figure 2 of the agent, message, and interpreter provided by UNESCO below can be the adoption of how governmental actors, non-governmental actors, and society, in general, can understand the circle of a hoax.

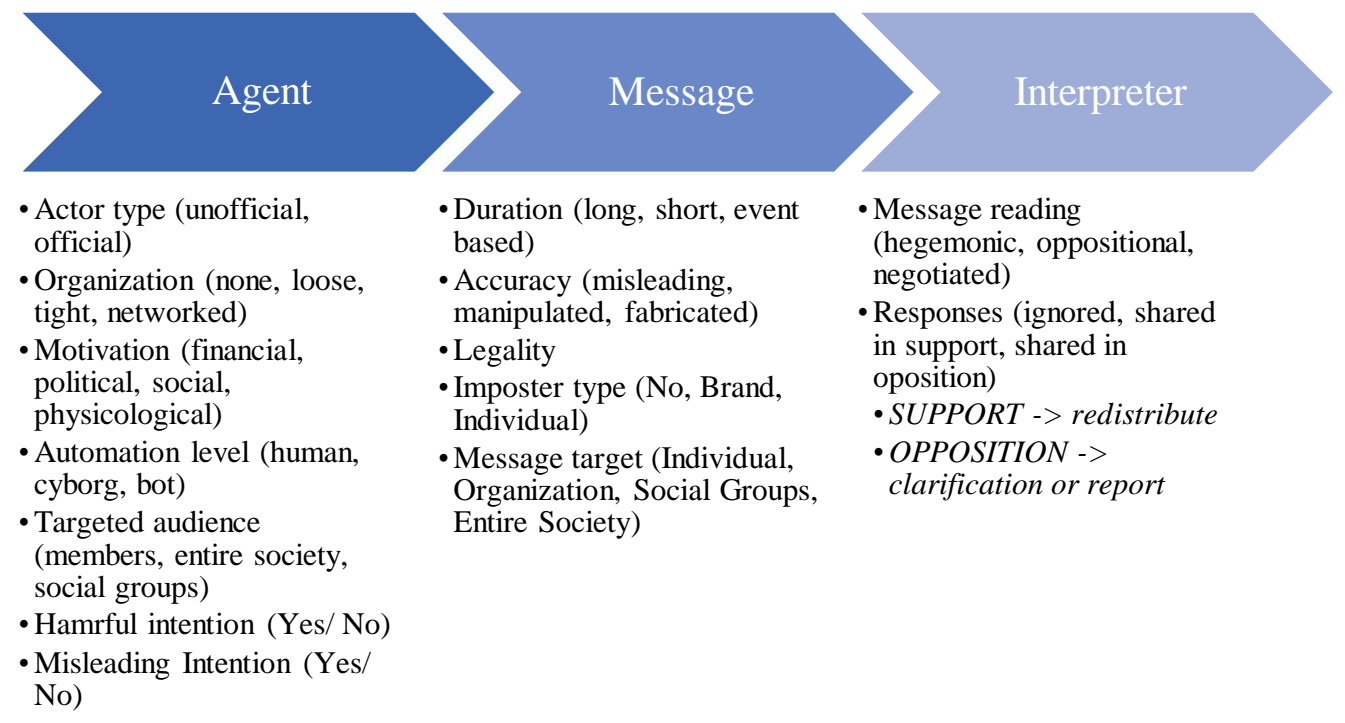

Fig. 2. Three Elements of Information Disorders (Agent, Message \& Interpreter) [4].

Using the same framework, it can be observed how law enforcer deals with the actor or imposter behind the hoax. The housewife case in the earlier scenario might not have sufficient understanding that what she did was wrong. Under the basis of a desire to be viral and no harmful intention, she might not be convicted for her hoax. However, this chain of hoax or false information distribution framework is not explicitly mentioned on the ITE Law and its revision nor mentioned on the hoax handling method of POLRI or Kominfo's released document and public website. What can be mainly observed from the regulation and government institutions' roles in implementing it is the applicable law principle related to Indonesia's hoax. 


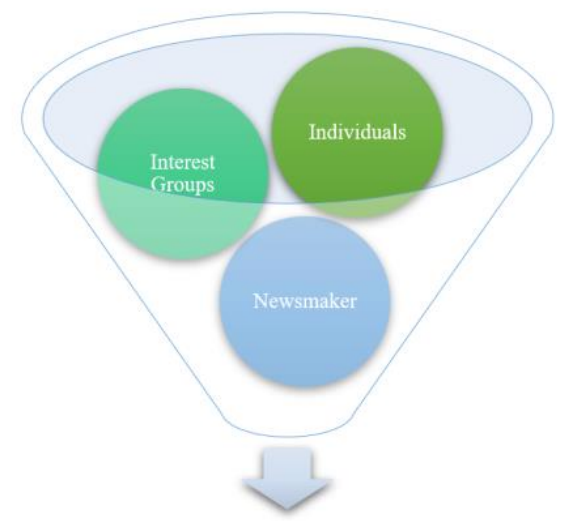

Hoax/False Information/Fake News

Fig. 3. Main Actors in Hoax Creation and Distribution in Indonesia (Source: Author's interpretation based on the various report on hoax in Indonesia).

The acknowledgment of different actors' acts also leads to a different distribution of hoaxes and fake news in general. The analysis level based on the following can help understand different actors of individuals, newsmakers, and interest groups.

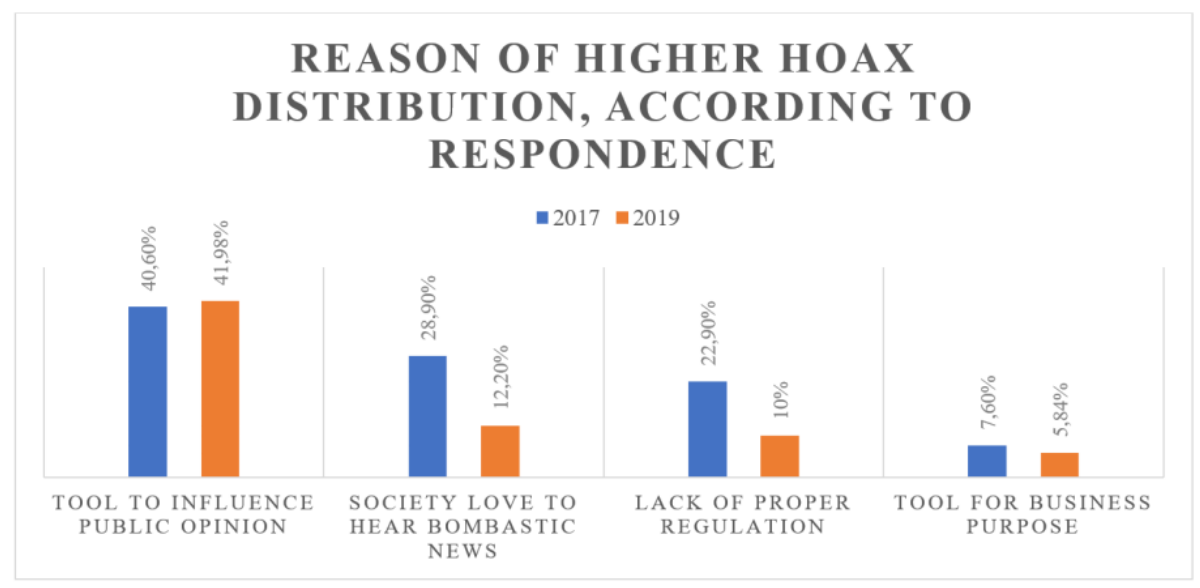

Fig. 4. National Survey Report on Hoax 2019 [6].

In the meso-level of analysis, there is a novel discovery on how mainstream media or traditional media, such as news outlets or media corporations, can also distribute fake news. The term "fake news" here is relevant to be used due to the facts that journalist is a big part of the media as news producer organization. Various factors cause the existence of fake news in the mainstream media. Four primary and most popular reasons are captured by Tsfati et al. [7], such as "(a) perception of the journalist, (b) traditional news values, (c) psychology of news decision, 
(d) infrastructure for covering the cyberspace information". Four causes are correlated to the idea of mainstream media as it also has the purpose of publicity and marketing.

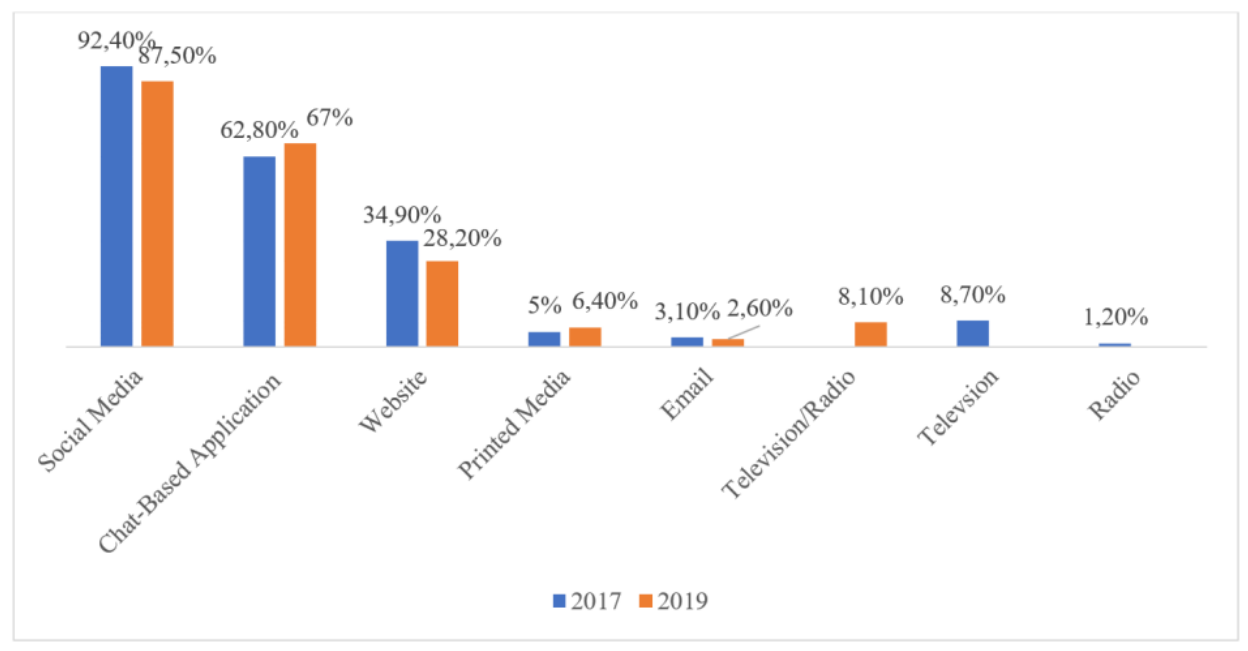

Fig. 5. Distribution Channel of Hoax in Indonesia 2017, 2019 [6].

From the socio-legal perspectives, circulating the hoax is massively prevalent nowadays since many individuals are unaware of the content and find it worthy of sharing without breaking the ITE law and its revision. What makes it more adverse is when individuals do not have the intention to spread false information and yet at the same time do not understand the consequences of what they share. ITE law and its revision have made it law-binding enough to charge someone for their acts in creating, distributing, redistributing, or even modifying the false information. However, the measurement on whether such socialization regarding the ITE law and its revision have been adequately disseminated has not yet been disclosed. An increasing amount of hoax even when there is no political competition momentum.

This similar notion on the multiverse causes of hoax is confirmed with the survey conducted by Mafindo or Anti Hoax Society in Indonesia (Masyarakat Anti Fitnah Indonesia) on their database [8]. In the report, it can be examined that even though hoax related to politics or political candidates were indeed declined sharply in August 2019 (4 months after the General Election in April 2019), hoax related to other topics were still present, such as religion, health, natural disaster [8].

\subsection{POLRI and Their Policy Approach to Combat Hoax and Fake News in Indonesia}

It has been highlighted in the previous part of this essay that hoaxes and false information are all damaging to various layers in society and must be fought nationally. One of the key actors to combat hoaxes and false information in Indonesia is the police. The general tasks performed by the POLRI are based on their primary responsibility of keeping the citizens of the Republic of Indonesia safe. Meanwhile, this core responsibility has three subsets of approaches: brief explanations below. It will be elaborated to overview the hoax and fake news policy approach by the National Police of Indonesia. 


\subsubsection{Preemptive Approach}

The efforts and activities are made to face the issue by socializing within the public sphere to prevent any unlawful act in society. Another term mentioned by the POLRI is "Community Policing", yet the term itself is considered bias because it might be obsolete in the smaller region parts of the country. The embodiment of "Community Policing" was vivid back in the day with what society refers to as Sistem Keamanan Lingkungan (Siskamling) or Environment Security System that is overviewed by the local representative of the Local Police, namely Bhabinkamtibmas (Bhayangkara Pembina Kamtibnas). Aligned with what is suggested on POLRI's website, there have been some outdated conditions and disconnection between Community Police and the Bhabinkamtibmas. The connection is rather loose, and there seems no urgency to ensure the overall monitoring process of Community Policing. Besides the presence of Bhabinkamtibmas, the National Army of Indonesia (TNI) also has the same functioning part in the society as the local representative of the Local Army, namely Babinsa.

\subsubsection{Preventive Approach}

Suppose the preemptive approach showcases the importance of engaging with society as anticipating certain illegal activities. In that case, preventive measures ensure that the police exercise their function to prevent potential threats from occurring. This approach can be considered guarding society with the protection measure to prevent any illegal acts in society. The examples can be seen on the regular patrols, crime investigation, and security approach. In this approach, coordination with society is also crucial. Although similar to the preemptive approach, the preventive approach's main aim is instead to utilize police resources to prevent the occurrence of illegal acts within society.

\subsubsection{Repressive Approach}

The last approach specifically mentioned and introduced under the law to highlight the POLRI's responsibilities and legitimate actions is repressive. We may interpret repressive as the law enforcement approach where POLRI can perform lawful penalty and action to the vigilantes [9]. This approach is usually the last resort taken by POLRI if the preemptive and preventive approach's failure persists. However, it must be acknowledged that this approach must be taken after careful lawful consideration and legitimate investigation that are valid legally. This validation is important for POLRI as a law enforcer who will have to face vigilantism in society, including digital vigilantism. Therefore, the repressive approach by POLRI must ascertain the character of criminal justice and can be confirmed with the overall criminal justice system in Indonesia. Substantially, the search and investigation process are explained to include the following: a. search, inspect, and investigate a phenomenon that can be considered as a crime, b. decide on the further investigation, $c$. find the evidence, d. clarify the crime, e. find a criminal based on the overall investigation and evidence. This series of investigation process done by POLRI is salient to the hoax and fake news investigation process. However, the method might be distinct due to its nature from police perspectives to analyze certain cases based on non-hard evidence. 


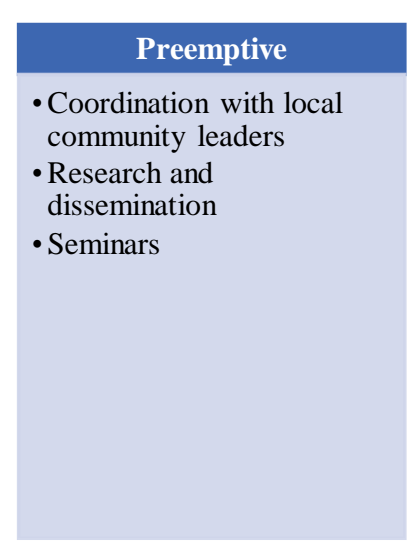

Preventive
- Initiation of the new
Directorate of Cybercrime Act
[10]
- Cyber patrol (creation of
different channels for cyber
patrol, such as: website, social
media (Twitter, Instagram,
Facebook) [11]
- Coordination and
collaboration with Ministry of
Informatics, Communication
and State Cyber and Code
Agency (BSSN), third party
actors to provide monitoring
and reporting.

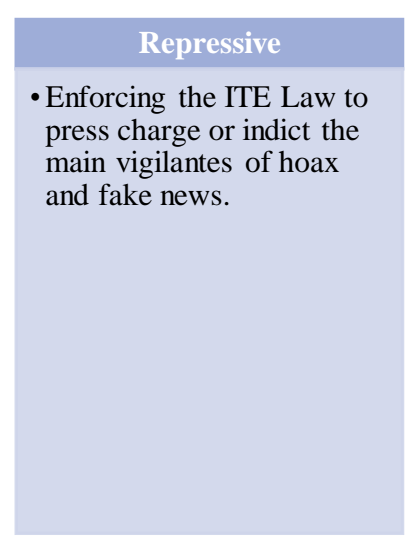

Fig. 6. Examples Preemptive, Preventive \& Repressive Policy by POLRI Since ITE Law Revision in 2016 [10][11].

By classifying different policy approaches that POLRI has taken so far, we understand that there must be some significant efforts done by POLRI as well as other actors. Among the three, the preemptive policy regarding hoaxes and fake news is considered trivial. The writer found some sporadic events, but since its initiation is not continuous, the efforts to communicate with the public are meager.

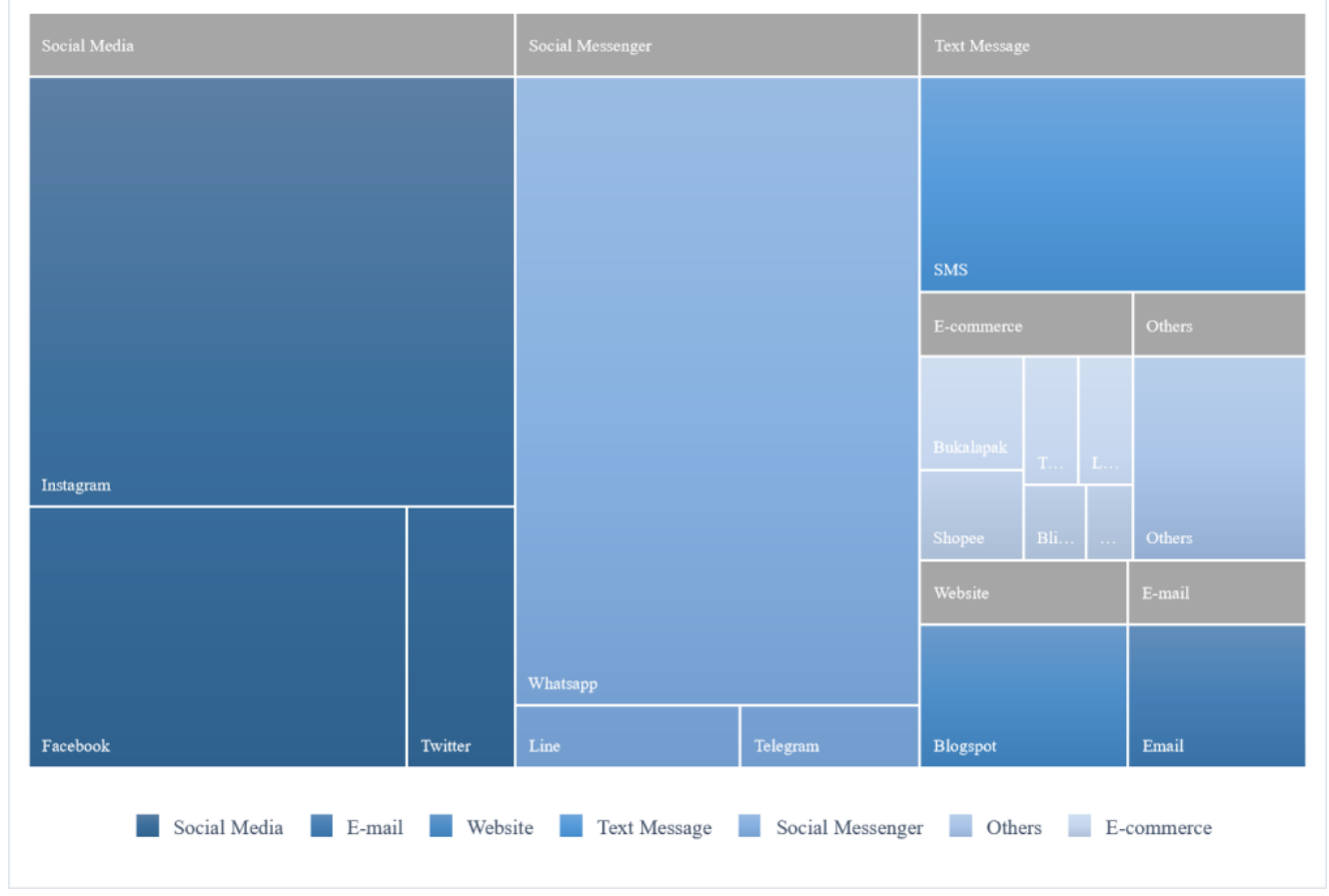

Fig. 7. Reported Platforms Based on Patrolisiber.id (2017-2020) [12]. 


\subsection{Challenges Faced by POLRI to Combat Hoax and Fake News in Indonesia}

Throughout this essay, it has been mentioned that efforts to conduct policy to reach specific social impacts by combatting and eschewing concerns are not facile. For instance, in preemptive and preventive approaches, POLRI has to construct, deconstruct, reconstruct, and even consolidate different reports and investigation findings in a variety of hoaxes and fake news with limited resources. Indeed, it is not a task that can be oversimplified, especially in a democratic society with a complex arena, such as Indonesia. Despite their role as law enforcers, POLRI is challenged to connect community ideas and their responsibility to investigate. Such a phenomenon is captured by Howlett [13] to acknowledge the importance of closely integrated communities as well as cohesive process to promote innovative policy in subsystem structure. However, the components of POLRI's approaches cannot neglect the obstacles that they face in this multicultural societal subsystem.

In the context of hoaxes and fake news, at the moment, POLRI has always relied on reporting sourced from the citizens/people. However, some challenges are faced, such as inadequate data and reporting sources, lack of coordination with other stakeholders, lack of societal understanding of the importance of fact-checking information. There is also an urgency for defining and setting the parameter of success.

\section{Conclusion}

This paper has ultimately scrutinized and discussed hoax and fake news discourse as part of multifaceted information disorder in Indonesia. The National Police of Indonesia or POLRI's policy focus on tackling these information disorders, hoaxes, and fake news. What continues to lack is the specific proportion to include a clear definition of the information disorders, especially in the scope of the police's preventive and preemptive policy. POLRI has focused on three key approaches in implementing its efforts to minimize and even combat hoaxes and fake news. However, it must also be highlighted the fundamental understanding of its definition and which actors they should focus on so that their investigation can be seamless in the future. At the moment, their official website focuses on the distribution of disinformation and misinformation rather than the source.

\section{References}

[1] Centre for International Governance Innovation and Ipsos (CIGI - Ipsos), "CIGI - Ipsos global survey on internet security and trust 2019 Part 3: Social Media, Fake News \& Algorithms,” 2019. https://www.cigionline.org/sites/default/files/documents/2019\%20CIGIIpsos\%20Global\%20Survey\%20-

\%20Part\%203\%20Social\%20Media\%2C\%20Fake\%20News\%20\%26\%20Algorithms.pdf.

[2] H. Poesoko and A. A. S. L. Dewi, "The Role of Legal Opinion as Legal Problem-Solving Method," Sociol. Jurisprud. J., vol. 3, no. 1, pp. 19-27, 2020.

[3] J. Gijssels, M. Van Hoecke, and B. A. Sidharta, Apakah teori hukum itu? Bandung: Laboratorium Hukum Fakultas Hukum Universitas Katolik Parahyangan, 2000.

[4] C. Ireton and J. Posetti, Journalism, fake news \& disinformation: handbook for journalism education and training. Paris: Unesco Publishing, 2018. 
[5] C. Wardle, "First draft's essential guide to understanding information disorder," First Draft, 2019, [Online]. Available: https://firstdraftnews.org/wpcontent/uploads/2019/10/Information_Disorder_Digital_AW.pdf?x76701.

[6] Mastel, "Hasil survey Mastel tentang wabah hoax nasional. Jakarta: Masyarakat Telematika Indonesia," 2019. https://mastel.id/hasil-survey-wabah-hoax-nasional-2019/.

[7] Y. Tsfati, H. G. Boomgaarden, J. Strömbäck, R. Vliegenthart, A. Damstra, and E. Lindgren, "Causes and consequences of mainstream media dissemination of fake news: literature review and synthesis," Ann. Int. Commun. Assoc., vol. 44, no. 2, pp. 157-173, 2020.

[8] Mafindo, "Executive Summary 013/2019 Komite Litbang Mafindo Pemetaan Hoaks 2019," 2019. https://www.mafindo.or.id/wp-content/uploads/2020/06/Mapping-Mafindo-2019-1.pdf.

[9] D. E. Listianto, "Police Role Big City of Semarang in Vigilantism (Eigenrechting) Prevention by Society," J. Daulat Huk., vol. 1, no. 4, pp. 915-920, 2018.

[10] Divkum POLRI, "Peraturan Kepolisian Negara Republik Indonesia Nomor 5 Tahun 2019 Tentang Perubahan atas Peraturan Kepala Kepolisian Negara Republik Indonesia Nomor 6 Tahun 2017," 2017. http://portal.divkum.POLRI.go.id/Documents/PERPOL 5 TH2019SOTKMABESGABUNG-dikompresi (1).pdf.

[11] Patrolisiber.id, "Direktorat Tindak Pidana Siber Bareskrim POLRI," 2020. https://patrolisiber.id/contact.

[12] Patrolisiber.id, "Jumlah Laporan Polisi yang dibuat masyarakat," 2020. https://patrolisiber.id/statistic.

[13] M. Howlett, "Policy analytical capacity and evidence-based policy-making: Lessons from Canada," Can. public Adm., vol. 52, no. 2, pp. 153-175, 2009. 


\section{Appendix}

Classification of New and Modified Socio-Legal Characters of ITE Law

\begin{tabular}{|c|c|c|c|}
\hline Type of cybercrime & $\begin{array}{l}\text { Articles on } \\
\text { the ITE Law } \\
\& \text { The } \\
\text { Revision }\end{array}$ & $\begin{array}{l}\text { Contemporary/ New } \\
\text { Socio-Legal } \\
\text { Character (YN) }\end{array}$ & $\begin{array}{l}\text { Modified Socio- Legal Attributes } \\
\text { (Y/N) }\end{array}$ \\
\hline $\begin{array}{l}\text { Hacking (although not specifically } \\
\text { mentioned as a term, but the articles } \\
\text { describe the hacking/ breaching into } \\
\text { somebody's computer/ electronic system } \\
\text { activities, therefore can be considered as } \\
\text { hacking) }\end{array}$ & $\begin{array}{l}\text { Article 30, } \\
\text { ITE Law }\end{array}$ & $\mathrm{Y}$ & \\
\hline $\begin{array}{l}\text { Illegal cyber/intemet tapping (explicitly } \\
\text { mentioned) }\end{array}$ & $\begin{array}{l}\text { Article 31, } \\
\text { ITE Law }\end{array}$ & $\mathrm{Y}$ & \\
\hline $\begin{array}{l}\text { Infringement, cyber theft, forgery, as well } \\
\text { as unauthorized data/file sharing }\end{array}$ & $\begin{array}{l}\text { Article } 32 \\
\text { ITE Law }\end{array}$ & $\mathrm{Y}$ & \\
\hline $\begin{array}{l}\text { Cyber interference and sabotage over } \\
\text { internet connection system or cyberspace } \\
\text { (cyber-terrorism) }\end{array}$ & $\begin{array}{l}\text { Article 33, } \\
\text { ITE Law }\end{array}$ & $\mathrm{Y}$ & \\
\hline $\begin{array}{l}\text { Those who are involved in the process of } \\
\text { cyber-terrorism }\end{array}$ & $\begin{array}{l}\text { Article } 34, \\
\text { IrE Law }\end{array}$ & $\mathrm{Y}$ & \\
\hline Data forgery and identity theft & $\begin{array}{l}\text { Article } 35 \\
\text { ITE Law }\end{array}$ & $\mathrm{Y}$ & $\begin{array}{l}\text { Somewhat Yes, but not regulated } \\
\text { under KUHP or other specific law }\end{array}$ \\
\hline $\begin{array}{l}\text { Illegal content 1: Decency, including } \\
\text { pormography }\end{array}$ & $\begin{array}{l}\text { Article 27, } \\
\text { ITE Law }\end{array}$ & & $\begin{array}{l}\mathrm{Y} \text {, also covered in the Law no } 44, \\
2008 \text { on Pomography and KUHP }\end{array}$ \\
\hline $\begin{array}{l}\text { Illegal content 2: Gambling (not } \\
\text { specifically categorized, but everything } \\
\text { that includes any content relevant to } \\
\text { gambling) }\end{array}$ & $\begin{array}{l}\text { Article 27, } \\
\text { ITE Law }\end{array}$ & & $\mathrm{Y}$, also covered in the KUHP \\
\hline Illegal content 3: Defamation (online) & $\begin{array}{l}\text { Article 27, } \\
\text { ITE Law }\end{array}$ & & $\mathrm{Y}$, also covered in the KUHP \\
\hline Illegal content 4: Blackmailing & $\begin{array}{l}\text { Article 27, } \\
\text { ITE Law }\end{array}$ & & $\mathrm{Y}$, also covered in the KUHP \\
\hline $\begin{array}{l}\text { Illegal content 5: Fraud using false } \\
\text { information that causes consumer's loss }\end{array}$ & $\begin{array}{l}\text { Article } 28 \\
\text { Section } 1 \\
\text { ITE Law }\end{array}$ & & $\begin{array}{l}\mathrm{Y}, \text { also covered in the Law no } 8 \text {, } \\
1998 \text { on Consumer Protection }\end{array}$ \\
\hline $\begin{array}{l}\text { Illegal content 6: False information that } \\
\text { creates hate over individual, politics, }\end{array}$ & $\begin{array}{l}\text { Article 28, } \\
\text { Section } 2\end{array}$ & & $\begin{array}{l}\mathrm{Y} \text {, also covered in the KUHP and } \\
\text { other law. }\end{array}$ \\
\hline $\begin{array}{l}\text { ethnic group, race, religion, and particular } \\
\text { group. }\end{array}$ & ITE Law & & $\begin{array}{l}\text { 1. Article } 390 \text { KUHP also } \\
\text { covers similar notion of } \\
\text { false information but } \\
\text { explicitly mention the } \\
\text { distribution of it. } \\
\text { 2. Article } 14 \text { \& } 15 \text {, Law no } \\
\text { 1, } 1946 \text { about Criminal } \\
\text { Law }\end{array}$ \\
\hline Illegal content 7 : Threats of violence & Article 29 & & $\begin{array}{l}\mathrm{Y} \text {, also covered in the KUHP and } \\
\text { other laws }\end{array}$ \\
\hline
\end{tabular}

Source: Author's interpretation based on related Laws (KUHP, ITE Law and Revision, Consumer Protection Law, and Pornography Law). 